\title{
THE ROOTS OF TRADITIONAL ISLAM IN MODERNIST MUSLIM WORKS: K.H. Aceng Zakaria and the Intellectual Tradition of Pesantren
}

\section{Jajang $\mathcal{A}$ Rohmana}

Universitas Islam Negeri Sunan Gunung Djati Bandung, Indonesia

E-mail: jajangarohmana@uinsgd.ac.id

\section{Abstract}

One of characters of modernist Islam organization in Indonesia is the opposition to traditionalist Islam practices. Initially, the modernist Islam activist also learned in the traditional Islam culture before they turned around. This study focuses on the roots of the traditional Islam among the modernist Islam organization activists, Islamic Union (Persatuan Islam/PERSIS). The study object is the historical life of the PERSIS chairman, Aceng Zakaria and his magnum opus works, al-Muyassar fì 'Ilm alNahw and al-Hidâyah fì Masâ'il Fiqh Muta'âridah. Through a sociointellectual historical approach, the study shows that the Islamic intellectual tradition of the modernist activists is inseparable from the learning of traditional pesantren. Aceng Zakaria, as a PERSIS ulama, originally learned at the traditional pesantren in the mid-twentieth century. The roots of traditional Islamic science influences his intellectual career which was reflected in his works. Both books, Arabic grammar al-Muyassar and figh discourse al-Hidâyah demonstrate his connectivity to the intellectual of traditional pesantren. However, Aceng Zakaria, as a modernist and reformist ulama, also modified his explanation systematically and practically. This shows that the genealogy of intellectual tradition of pesantren has an important position in supporting the development of reformist Islamic ideas in Indonesia. 
Salah satu karakter organisasi Islam modernis di Indonesia adalah penentangan terhadap praktik Islam tradisional. Namun, para aktivis Islam modernis itu awalnya juga dididik dalam budaya Islam tradisional sebelum kemudian mereka berbalik arah. Kajian ini memfokuskan pada akar Islam tradisional di kalangan aktivis organisasi Islam modernis, Persatuan Islam (PERSIS). Objek kajian ini adalah sejarah kehidupan Ketua Umum PERSIS, Aceng Zakaria dan karya magnum opus-nya, yaitu kitab alMuyassar fî 'Ilm al-Nahww dan al-Hidâyah fî Masâ'il Fiqh Muta'âridah. Melalui pendekatan sejarah sosial-intelektual, kajian ini menunjukkan bahwa tradisi keilmuan Islam di kalangan modernis tidak dapat dipisahkan dari keilmuan pesantren tradisional. Aceng Zakaria misalnya, sebagai ulama PERSIS, awalnya dididik di pesantren tradisional pada pertengahan abad ke20. Akar keilmuan Islam tradisional itu berpengaruh terhadap karir intelektualnya yang tercermin dalam karyanya. Buku grammar bahasa Arab al-Muyassar dan diskursus fikih dalam kitab al-Hidâyah memperlihatkan keterhubungannya dengan tradisi intelektual pesantren tradisional. Namun, sebagai seorang modernis sekaligus reformis, Aceng Zakaria juga melakukan modifikasi pembahasan secara sistematis dan praktis. Ini menunjukkan bahwa genealogi tradisi intelektual pesantren memiliki posisi penting dalam menopang perkembangan gagasan Islam reformis di Indonesia.

Keywords: kitab kuning; PERSIS; pesantren; reformist; traditionalist;

Received: August 23, 2021; Accepted: November 30, 2021

\section{Introduction}

Islamic discourse in Indonesia has been marked by the issue of strengthening the identity of Islam Nusantara (Archipelagic Islam) for almost the past six years (Sahal and Aziz eds. 2015; Hasyim 2018; van Bruinessen 2018). It is an expression of Islam in Southeast Asia that is generally practiced in Indonesia and its neighboring countries such as Malaysia, Singapore, Brunei Darussalam, The Philippines, and Southern Thailand. Islam Nusantara has become the official jargon of the Nahdlatul Ulama (NU) since the 33rd National Congress in Jombang on August 1-5, 2015. This is a response to the growing threat of transnational Islam which influenced the increase of radicalism and terrorism in Indonesia (Burhani $2018,5)$. Islam Nusantara is defined as an interpretation of Islam based on the moderation and justice values. This idea emphasizes the uniqueness of 
Islamic identity in the Malay-Indonesia archipelago which accept differences based on the spirit of blessing to the universe or rahmatan lil âlamîn (Hamdani 2021, 21-39).

However, the idea of Islam Nusantara then raised many responses. Islam Nusantara is not only accused of being the product of a liberal group within NU which is trying to localize universal Islam (Arifianto 2017, 1), but also simply used as the political agenda by a group which Nakamura (1981, 190) called the proponent of "radical traditionalism." This group claims to be the sole heir to the Islamic tradition in the Malay-Indonesia archipelago. This claim ignored the role of other Islamic organizations such as Muhammadiyah and PERSIS which also rised in the Islamic tradition in Indonesia. There is an assumption that Islam Nusantara as the interpretation of Islam based on the legacy of traditional Islam. It was then confronted with reformist-modernist Muslims who have become opponents of traditionalist Muslim since the early twentieth century (Noer 1963, 494). This is an exclusive viewpoint on the long path of Islamic networks in the Malay-Indonesia archipelago in the midst of the dynamics of continuity and change until now.

The emergence of modernist Muslim organizations in the early twentieth century historically was a response to the issue of Islamic reform in Egypt, Islamic modernity and European colonialism (Nakamura 1976, 98; Federspiel 2001, 186). The wave of Islamic reform idea then influenced the discourse of Muslim thought in other regions including the MalayIndonesia archipelago (Burhanudin 2005, 10-1). Traditionalist Muslim organization such as NU responded to this Islamic reform issue by reaffirming the importance of the traditional roots of Islam in the MalayIndonesia archipelago (Bush 2009, 14).

However, both the modernist and traditionalist Muslim movements are genealogically rooted in the similar tradition of intellectual Islam. Both K.H. Ahmad Dahlan (1868-1923) as a founder of Muhammadiyah and K.H. Hasyim Asy'ari (1871-1947) as founder of NU studied under Sheikh Ahmad Khatib Minangkabau in Mecca at the end of the nineteenth century (Shihab 1995, 173). Likewise, both Haji Zamzam and Haji Muhammad Yunus as founders of PERSIS were influenced by traditional Islamic learning in their villages before making a connection with the idea of Islamic reform through the al-Manâr magazine from Egypt and al-Munir from Padang (Federspiel 2001, 84). The similar experience was obtained by A. Hassan, the main teacher of PERSIS, who initially taught by 
traditionalist ulamas in Malacca and Singapore such as Muhammad Thaib and Sa'id Abdullah al-Musawi (Minhaji 1997, 86). In recent times, other PERSIS figures such as M. Natsir, Isa Anshary and M. Rusyad Nurdin also initially learned from traditionalist ulamas in their villages in West Sumatra (Wildan 1997, 53, 92; Mustafa 2005). This is also experienced by K.H. E. Abdurrahman (1912-1983), a second generation ulama of PERSIS as well as A. Hassan's student, who initially studied the traditional Islamic knowledge at the Pesantren al-I'anah Cianjur under the guidance of Raden Haji Mohammad Nuh (1879-1966), the father of K.H. Abdullah ibn Nuh (19051987), well-known Sundanese ulama of Cianjur (Hakim 2009, 15). Therefore, the Islamic reformism movement initially cannot be separated with the intellectual tradition of traditional Islam in the Malay-Indonesia archipelago that has been rooted for a long time, even though the modernist Islam is known as the main opponent of traditional Islam.

One of the PERSIS ulamas who also connected with the intellectual tradition of traditional Islam is K.H. Aceng Zakaria (b. 1948), a respected ulama and chairman of PERSIS from 2015-2021. His character as a PERSIS ulama is rooted in the educational background at traditional pesantrens in Wanaraja Garut. He then studied at the Pesantren PERSIS Pajagalan in Bandung under the guidance of E. Abdurrahman, chairman of PERSIS from 1962-1983. In addition, the productivity of Aceng Zakaria who published hundreds of books is inseparable from the influence of intellectual tradition of the traditional pesantren (Fauzan et al. 2021, 21822).

This study focuses on the roots of intellectual tradition of traditional Islam in the works of Aceng Zakaria. This study uses a socio-intellectual historical perspective to reveal the traces of the connectivity of the reformist intellectual tradition with the traditional pesantren in Priangan. The sociointellectual history approach is intended as a history of thought in the past which is influenced by dynamics situation (Stearns ed. 1994, 608; MacRaild and Taylor 2004, 18). This study uses this approach to analyzes social intellectual factors in the intellectual tradition of traditional pesantren that affect Aceng Zakaria's historical experience as reflected in his works. The study will mainly focus on two of Aceng Zakaria's magnum opus works, alMuyassar fì 'Ilm al-Nahw (The ease in Arabic grammar) and al-Hidâyah fî Masâil Fiqh Muta'âridah (A guidance on the issue of figh contradictions) (Zakaria ibn Ahmad Kurhi 2007; 1407 H). Both al-Muyassar and al-Hidâyah 
are important to be analyzed relating to the author's connectivity with the intellectual tradition of traditional pesantren. The tradition of pesantren has an important position in supporting Aceng Zakaria's thought as a reformist ulama in Indonesia.

The article confirms that Aceng Zakaria as the chairman of PERSIS is basically influenced by the intellectual tradition of traditional Islam. PERSIS is Islamic organization which is always considered small but influential in the idea of rigid and puritanical conservative reformism (van Bruinessen 2003, 171). Although several scholars have studied the figure of Aceng Zakaria and his works, there are not many scholars who considered the intellectual tradition of traditional pesantren as an important factor for his career as an ulama of PERSIS (Sa'adah 2018; Amalia 2017; Fauzan et al. 2021). Some scholars even give an inaccurate analysis of Aceng Zakaria's thought which considered to be "progressive Salafi" (Happy 2020). Therefore, this article explains the important argument of considering the roots of traditional Islamic culture in the reformist Muslim activists in the early twentieth century. The intellectual tradition of traditional Islam as the basic learning of the reformist Muslim activists reflects the continuity of Islamic thought in Indonesia which is in line with the learning of the traditional pesantren. It is a dynamics of the Islamic movement that reflects the continuity and change of Islamic thought in response to local Islamic culture, on the one hand, and the issue of Islamic modernity, on the other hand.

\section{PERSIS and the Roots of Traditional Islam}

PERSIS was founded on September 12, 1923. This Islamic organization was not born in a historical vacuum. The wave of reform issues in Egypt, Hijaz, and Southeast Asia since the end of the nineteenth century became one of the triggers (Federspiel 2002, 373-4). The migration of Sumatran people from Minangkabau to urban areas in Java made the idea of Islamic reformism even reach Priangan in West Java. Many immigrants initially left their homes to avoid the Padri war, traded, and studied in educational institutions that were known to be more advanced and developed in Java (Asnan in Abdullah 2015, 396-404).

Bandung is one of the choices for the immigrants compared to other urban areas in Java. This cosmopolitan city has been known as an area where various ethnic groups lived such as Europeans, Arabs, Chinese, Malays, Indians, and others. Bandung and its surrounding cities in West 
Java with natural beauties and advanced urban facilities tend to be open to accepting various religious beliefs (Rosidi ed. 2000, 96). Sundanese people no longer has a palace as a guardian of Sundanese tradition in filtering outside cultural influences since the collapse of the Sunda Kingdom in 1579. Islam can freely take on that cultural role after both Kingdoms of Cirebon and Banten which supported by the Islamic Mataram Kingdom ruled the West Java. This is then also supported by the Sundanese elite (ménak) who encourages more intense Islamization efforts (Millie 2009, 5).

The similarity of the socio-religious situation in Bandung and Minang would be one of the important factors in the migration wave of Minang people to West Java. Haji Muhammad Yunus, Haji Zamzam's family, Mohamad Hatta, M. Natsir, Isa Anshary, M. Rusyad Nurdin, and others are some of the Sumatran people who feel how the religious life in Bandung is similar to their homelands. This is characterized by the practice of Islamic traditions with easy access to absorb many information. A. Hassan feels the same since his coming from Singapore, then moved to Surabaya, until he finally decided to settle in Bandung (Minhaji 1997, 83-103). Some scholars argue that the puritanical pattern of Islamic understanding comes from the Sumatran people, as experienced by Muhammadiyah after the death of K.H. Ahmad Dahlan (Burhani 2004, 79-80).

Therefore, it is understandable that the phenomenon of Islamic reformism in Indonesia grew in urban rather than rural areas (Tamney 1980, 208). The city that allows a lot of socio-economic interaction from various ethnic groups from all over Indonesia and many countries allows for exchange of ideas easily. This has made it easy for Islamic reformism thought from the Middle East influences various cities in Java and Sumatra such as Minangkabau, Yogyakarta, Bandung, and other areas.

However, it is important to remember that the wave of Islamic reformism ideas will not succeed if not supported by the local Muslims who already lived in Bandung and its surrounding cities. The Sundanese people who are culturally open to Islam gave a positive response to the Sumatran immigrants and the reformist Muslim ideas that led to the establishment of PERSIS. PERSIS activists and other Islamic reformism organizations such as Madjlis Ahloes Soennah (MAS) Cilame also pointed out the importance of involving Sundanese Muslims in Priangan in strengthening the Islamic reformism idea (Iskandar 2001, 171). The emergence of the figure of E. Abdurrahman as the second generation of PERSIS after A. Hassan shows the contribution of the Sundanese Muslims. 
E. Abdurrahman is an important figure of how Sundanese santri who were raised in the intellectual tradition of traditional Islam strengthened the continuity of reformist Muslim ideas in West Java. He initially studied traditional Islamic knowledge at Pesantren al-I'anah in Cianjur before converting (taslim) into reformist Muslim organization, PERSIS, under the influence of A. Hassan (Wildan 1997, 125; Nugraha and Rohmana 2021, 351). His expertise in mastering traditional Islamic knowledge became one of the important reasons for A. Hassan to recruit him so as to add ammunition to strengthen the PERSIS resources.

Therefore, E. Abdurrahman became the starting point for the next PERSIS generation about the importance of hybridizing traditional Islam which was adapted into the reformist Muslim tradition. These conversion efforts were carried out in other basis area of PERSIS such as Garut, Cianjur, Tasikmalaya, and Ciamis. The "four din" figures (Zaenuddin, Komaruddin AS, Syihabuddin, and U. Djamaluddin), for instance, as PERSIS pioneers in Garut also came from traditionalists Muslim who converted to PERSIS. Several teachers at Pesantren PERSIS in Garut in the 1980s also showed symptoms of this conversion as happened to Asep Barchoya (elder brother of Aceng Zakaria), Dedeng, Ujang Juanda, Aceng Iyod, and others. Aceng Zakaria as a student of E. Abdurrahman convincingly experienced the conversion of religious understanding.

The conversion of traditionalist Muslim activists into PERSIS is a historical reality that cannot be ignored. PERSIS as a small organization in urban areas when was first founded could not have succeeded without attracting many traditionalist Muslim figures. The experience of $\mathrm{E}$. Abdurrahman who was influenced by A. Hassan chose to retire from the traditional educational institution in Bandung and then joined the Pesantren PERSIS Pajagalan. His experience shows an awareness of the differences between traditionalist and modernist Muslim teachings at that time. PERSIS which is not yet large with a few followers makes important way to recruit new followers with the conversion process. Therefore, the path of debate and publication of Islamic books and magazines is very important to reach traditional Muslims who are generally not affiliated with certain Islamic organizations.

The conversion of Islamic understanding from traditionalist to modernist recently is not a priority for PERSIS. This is because it is already well established in producing many alumni and cadres by possessing their own intellectual tradition and educational system of modern pesantren. 
PERSIS activists were then increasingly dominated by the internal cadres of PERSIS in various areas who were generally the fourth generation. They continue in the footsteps of KH. A. Latief Muchtar (1931-1997) and KH. Shiddiq Amien (1955-2009) who was born and grew in internal intellectual tradition of the Pesantren PERSIS (Wildan 1997, 141; Saefuddin 2014). The third generation of PERSIS like Aceng Zakaria may be the last generation of conversion of traditionalist Muslims to PERSIS.

Therefore, it is important to emphasize that PERSIS tended to be Islamic modernism-reformism movement since its establishment in 1923. There is no traditional character in the PERSIS teachings although its founders individually coming from the traditional Muslim culture. This is related to the strong issue of Islamic reformism that came from Egypt to Sumatra and then became the subject of discussion among PERSIS founders whom were immigrants from Sumatra to Bandung. However, the spread of modernism-reformism ideas was successful after being supported by Sundanese Muslim traditionalists who converted and joined PERSIS. These traditionalist Muslims who converted to modernists then played a major role in supporting the PERSIS defense argument against the traditionalist ulamas. Both figures of E. Abdurrahman and Aceng Zakaria who were originally educated in the traditional pesantren and then converted to modernist movement show how effective modernist da'wa in West Java in the mid-twentieth century. It is important to explain Aceng Zakaria's biography and his works that will be discussed in next section.

\section{An Overview of K.H. Aceng Zakaria and His Works}

It is important to analyze the traces of traditional Islam in Aceng Zakaria's experience in order to show the importance of traditional Islamic roots in PERSIS. This section will briefly explain the background of Aceng Zakaria's life and his works until now. This is crucial so that his experience in the intellectual tradition of traditional pesantren can be well illustrated.

Aceng Zakaria was born in Sukarasa, Citangtu Village, Wanaraja District, Garut on October 11, 1948. His father was Kiai Ahmad Kurhi or Ajengan Engku. His grandfather, Kiai Shidiq or known as Mama Sukarasa, was a traditional ulama who pioneered the establishment of Pesantren Sukarasa in Wanaraja. Aceng Zakaria studied at the pesantren since childhood from his father. In addition, he also studied with his uncle, K.H. Payumi or Ajengan Uyum who is the younger brother of K.H. Yusuf Tojiri, a well-known ulama from Pesantren Cipari Wanaraja who had contact with 
Kartosuwiryo's DI/TII movement and later he had disagreements with him (Horikoshi 1975, 80; 1976, 24). Another teacher of Aceng Zakaria is Muallim Ansor who is the son of Mama Zakaria or Kiai Ba'ali, the founder of Pesantren Cilame. Aceng Zakaria received basic teaching of traditional pesantren from these three ajengans (ulamas) who learned about ten kitâbs such as al-Âjurûmiyyah, Saraf al-Kailânî, Tîjân, Safinah, and others.

Both Kiai Ba'ali and Yusuf Tojiri are known as modernist Muslim activists who have close relations with A. Hassan. They together with M. Romli, Muhammad Anwar Sanusi and several other modernist ulamas later founded the Majlis Ahli Soennah (MAS) Cilame, an organization that has been involved in many debates with traditionalist ulamas in Priangan (Rohmana 2017, 31). Aceng Zakaria's teachers (Ajengan Engku, K.H. Payumi and Muallim Ansor) studied with Kiai Ba'ali. It was reported that Kiai Ba'ali himself had studied at several pesantrens in Central Java.

In addition to studied at pesantren, Aceng Zakaria also received formal education at the Sekolah Rakyat Babakan Loa in Wanaraja until 1968. He then continued his education at Pesantren PERSIS Pajagalan in Bandung which headed by E. Abdurrahman, a PERSIS ulama who is also an alumni of the Pesantren al-I'anah in Cianjur. E. Abdurrahman already knew Muallim Ansor, Aceng Zakaria's teacher who lived in Garut. Aceng Zakaria then easily mastered the lessons at the Pesantren Pajagalan and even wrote an Arabic grammar book, because he already mastered the basic of traditional Islamic knowledge. He graduated in a short time, around 16 months. He then taught at the Pesantren PERSIS Pajagalan and also worked at a watch repair shop in Bandung to earn extra income.

However, Aceng Zakaria then moved to his hometown in 1975 based on the suggestion of PERSIS activists along with the pioneering of the establishment of the Pesantren PERSIS Bentar in Garut. He devoted himself as a main teacher at the pesantren. The good response from the Muslim community in Garut was able to increase the number of students (santri) at the pesantren from various regions in West Java. In 1994, Aceng Zakaria then pioneered the establishment of the Pesantren PERSIS No. 99 in Rancabango where he has been living at until now.

Aceng Zakaria is known as a PERSIS activist who build his career from the bottom line. He has been a PERSIS member in Garut in 1970s, then a chairman of branch and regional PERSIS and finally became the chairman of PERSIS from 2015-2021. His position as an ulama of PERSIS 
is recognized not only by PERSIS members and followers, but also nonPERSIS members. One of the proofs of his capacity as an ulama is his productivity to produced many Islamic works in Arabic, figh, Quranic commentary or tafsîr, hadith, and others. Following lists are some of his popular works granted with best sellers: al-Hidâyah fì Masâ'il Fiqhiyyah Muta'âridah, al-Muyassar fî 'Ilm al-Nahw, al-Kâfî fî̀ 'Ilm al-Sarf (Sufficiency in Arabic Inflection), Tarbiyyah al-Nisâ' fì Fiqh al-Mar'ah al-Sâlihah (Women Education on Figh), Do'a-doa Shalat, Do'a-do'a sehari-hari (Daily Prayers), Etika Hidup Seorang Muslim (Ethics of a Muslim's Life), al-Bâ'ith al-Mughîth fî 'Ilm al-Hadîth (Motivation on Hadîth Studies), Sakitku Ibadahku (My Pain is My Worship), Upaya Meraih Husnul Khatimah di Usia Senja (Efforts to Achieve Husnul Khatimah when Getting Old), al-Fatâwâ (Fatwas), Petunjuk Hidup Berjamaah Menurut Al-Qur'an dan al-Sunnah (Guidance for Living in Congregation According to the Quran and Sunna), and others (Fauzan et al. 2021, 218-22).

His works reached more than a hundred books which are generally simple and practical. At the beginning of his career, Aceng Zakaria compiled quite thick Arabic books intended for high-level students such as the book of al-Hidâyah. He calls his works as malumah (notices), not academic studies. Therefore, his works are mostly in the form of messages and simple teaching guidelines. This is understandable because Aceng Zakaria did not continue his undergraduate education. His formal education stopped after high school (mu'allimîn). Most of his works are intended for the public, from ordinary Muslim people in villages to professors in cities, who need practical Islamic knowledge for the daily practice. The figure of Aceng Zakaria until now has been well received by many people in West Java, because of his da'wa style that does not offend anyone. He also respected all his teachers from the traditionalist Muslim making his social relations with all circles run well.

\section{All About al-Muyassar and al-Hidâyah}

Aceng Zakaria's books of al-Muyassar and al-Hidâyah are among the most popular of his works. These two Arabic works are not only best sellers, but also the earliest works compiled in the middle of his career as a religious teacher at Pesantren PERSIS No. 19 Bentar Garut circa 1982-1985. After the success of these two works, Aceng Zakaria then published about hundred works in various fields of Islamic knowledge. 
Al-Muyassar fî ' Ilm al-Nahw is a learning and teaching book on Arabic grammar. This book is compiled in three volumes. The first volume initially was published in 1985, then followed by the second volume (1995) and the third one (1997). However, compared to the second and third volumes, the first one is the most popular. It has been printed and copied for so many times. Al-Muyassar was then followed by the more practical publication of Arabic grammar (nahw) textbooks such as Belajar Nahwu Sistem 40 Jam (40Hour System for Learning Nahwu) (2003); Belajar Nahwu Sistem 20 Jam (20Hour System for Learning Nahwu) (2017); and Belajar Nahwu Sistem 50 Jam (50-Hour System for Learning Nahwu) (2021). Al-Muyassar is widely used as a guidebook by teachers and lecturers for Arabic grammar learning in various institutions in Indonesia. This book was even taught through radio broadcasts in Garut so that many listeners from various backgrounds were attracted. The success story of al-Muyassar publication cannot be separated from the increasing enthusiasm for learning Islam and Arabic among the middle-class of urban Muslims after the reformation era in 1998 through fast and practical learning methods. It is understandable that practical guide books on Arabic grammar by Aceng Zakaria, like other practical guide books on Islam, are in great demand in the market, even from neighboring countries.

The discussion of the first volume of al-Muyassar begins with the definition and division of Arabic letters, words (al-kalimah), sentences (aljumlah al-mufidah), ism (noun), fi'l (verb) and noun forms such as marfû' (the nominative), manșûb (the accusative) and majrûr (the genitive). While the second and third volumes of al-Muyassar discussed a higher explanation in the form of an in-depth discussion of the basic concepts in the first volume. Aceng Zakaria (2007, d-h) explains the background and purpose of compiling al-Muyassar:

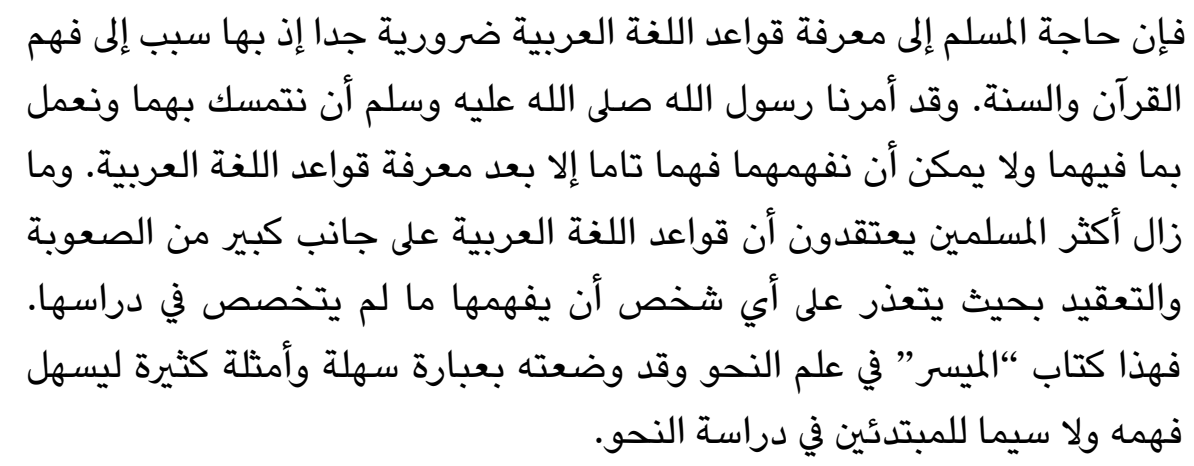




\begin{abstract}
"The need for a Muslim to know the rules of the Arabic language is important, because this knowledge becomes a means to understand the Quran and sunna. The messenger of Allah has commanded us to hold both the Quran and sunna. It is impossible to understand it completely unless you have knowledge about Arabic language rules. Many Muslims believe that the rules of Arabic are mostly difficult (to learn). This belief is based on the reasons for certain people who want to understand it but do not specifically learn Arabic. Therefore, this is al-Muyassar, the book on Arabic grammar. I compile it with an easy picture and lots of examples to make it easier to understand, especially for elementary-level students in learning nahw."
\end{abstract}

Above explanation shows that the compilation of al-Muyassar was motivated by the need of Muslims for studying the Quran and sunna. This reason actually demonstrates ideological motive of Aceng Zakaria as a reformist who tries to purify the teachings of the Quran and sunna. In addition, the reason of al-Muyassar preparation is also related to the belief of most traditionalist Muslims that the Arabic grammar knowledge is difficult to learn. Aceng Zakaria then tries to make it easier than before. This is based on his experience when studying traditional Islamic knowledge such as nahw for many years. He learned nahw since 10 years old through kitab kuning such as al-Âjurûmiyyah and Alfiyah Ibn Mâlik which are not easy to learn and need longer time to comprehend. His efforts to make it easier to learn nahw can be seen in his systematic presentation in al-Muyassar accompanied by examples, exercises, diagrams, and tables. This was not found in the kitab kuning studied in traditional pesantren.

Another work of Aceng Zakaria that shows traces of the intellectual tradition of traditional pesantren is Kitâb al-Hidâyah published in 1985. This book is his earliest and the most serious work with a fairly good academic discussion in the field of Islamic law or figh. Al-Hidâyah was originally a teaching material for PERSIS activist in Garut. This quite thick (350 pages) book, like other book of figh, discusses various controversial issues in fiqh with standard references from many kitab kunings. Based on the interview with Aceng Zakaria (Thursday $1 / 4 / 2021$ at 9 AM), there are no less than 130 Arabic kitâbs were used as references by mentioning the volume and page number. Al-Hidâyah is Aceng Zakaria's response to the discussion among students and traditional ulamas about various issues of figh on Islamic worship, heresy, taqlîd, prayers, cleanse after defilement, adhân, 
prayer, zakat, fasting, to gifts of rewards for the dead, the law of morality and forbidden food. This first edition of al-Hidâyah has not discussed the issue of hajj and umrah, because Aceng Zakaria had not yet performed the pilgrimage to Mecca at that time. Aceng Zakaria (1407 H, d-h) explains the purpose of the compilation of al-Hidâyah in his introduction:

ويعد ـ فإن الناس مطالبون بأن يعبدوا الله وحده ويعملوا بدينه الذي نزله لإصلاح شؤونهم الدنيوية والأخروية ويتمثلوا رسوله الذي أرسله بالهان بلهى ودئ ودين الحق كان لهم فيه أسوة حسنة وقدوة تامة لمن كان يرجوا الله واليوم الأخر.

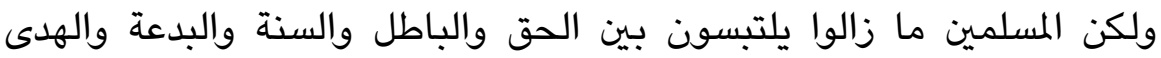

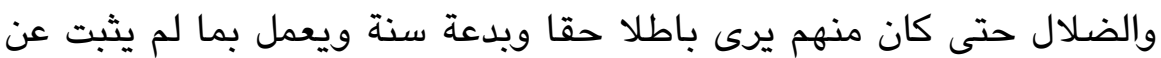
رسول الله صلى الله عليه وسلم. وقد قال رسول الله صلى الله عليه وسلم من بن

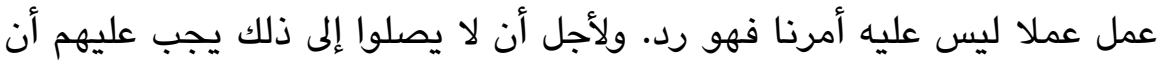

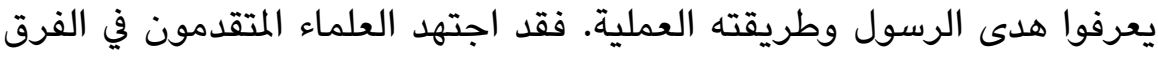

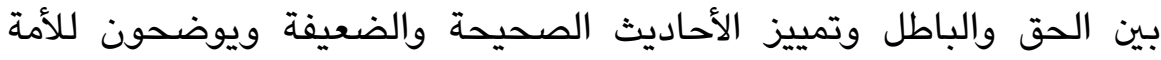

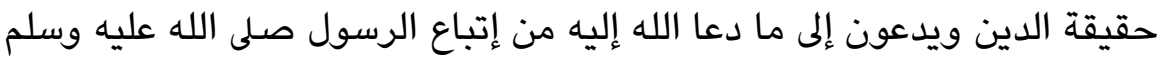

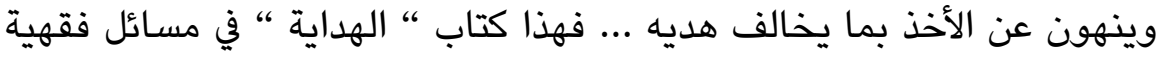
متعارضة أقدمه لإخواني المسلمين ليكونوا على بصيرة تامة في دينهم لا يشويهم

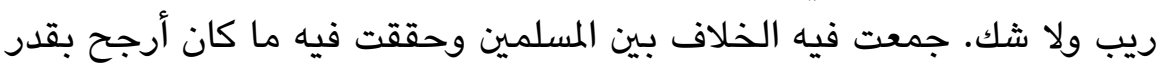
وسعى على ما قرأت من الكتب المتداولة بين أيدينا .

"Wa ba'd, humans want to worship the One God and practice their religions which He revealed, to improve their situation in this world and hereafter. They follow God's messenger sent with guidance and true religion. There is perfectly good example from His messenger for those who expect (reward) from Allah in the Last Day. However, Muslims always confuse the truth and falsehood, sunna and heresy, guidance and deviate until some of them view falsehood as truth and heresy as sunna. They do charity with something that is not determined from the messenger of Allah. The messenger said: "Whoever does a deed for which there is no command from us, it will be rejected." They must know the instructions of the messenger and how to practice it in order not to be rejected. Previous ulamas have ijtihâd (interpretative judgment) to distinguish between truth and falsehood; authentic and false of hadiths. They explain to all Muslims about the nature of Islam, invite to Allah's call, follow the messenger of Allah, and forbid 
taking anything that violates His guidance... The book al-Hidâyah discusses controversial issues in figh. I present this book to my Muslim brothers, so that they are in perfect insight in their religion, and not to be marred by doubt. I collect various differences opinion among Muslims in this book and analyze which one is the strongest based on my reading and breadth of my own books."

The above explanation shows that the publication of al-Hidâyah was based on Aceng Zakaria's experience who lived in the traditional Muslim societies. He claimed that their religious practices is blending sunna and heresy $\left(b^{\prime} d^{\prime} a\right)$. It is a typical reformist perspective that seeks to purify religious practice and returned to its pure teaching sources, the Quran and hadith. Therefore, al-Hidâyah is one of the important books among PERSIS followers, because it was written by a reformist ulama who has traditional Islam background. Al-Hidâyah is considered to be one of the best reformist books because the author knows the weaknesses of the traditional Islam arguments so that they are easy to break. According to Fauzan (10/10/21), a lecturer of STAIPI, many PERSIS preachers in Garut received teachings of al-Hidâyah through special training of preacher cadres (tamhîd al-muballighîn) taught directly by Aceng Zakaria in the 1990s. They then often use alHidâyah in arguing with traditionalist Muslims on controversial issues in fiqh. The references of al-Hidâyah which use many popular kitâbs in the traditionalist Muslim circles are the special quality of this book as an important source that turns against the arguments of traditionalist Muslims.

\section{Al-Muyassar, Al-Hidâyah, and the Intellectual Tradition of Pesantren}

In addition to Aceng Zakara's background which is connected to the intellectual tradition of traditional pesantren, the traditional Islam traces also appear in his works as seen in his books i.e. al-Muyassar and al-Hidâyah. Therefore, this section will explain the context of the intellectual tradition of traditional pesantren in the works of Aceng Zakaria. Although al-Muyassar and al-Hidâyah published in the reformist Islamic circles, both cannot be separated from the roots of the intellectual tradition of traditional pesantren. These works are important as objects of study. In addition to getting good response from PERSIS followers and even becoming best sellers, al-Muyassar and al-Hidâyah were also written at the beginning of Aceng Zakaria's career as a PERSIS ulama from 1982-1985. These works demonstrate the strongest 
indicators of the intellectual tradition of traditional pesantren compared to his other works.

1. Al-Muyassar and Arabic instrumental science in the traditional pesantren

The learning tradition of instrumental science ("ilm al-âlât) such as nahw (syntax), șarf (inflection) and balâghah (rhetoric) in traditional pesantren has long attracted the attention of scholars. Drewes, van den Berge, and van Bruinessen have explained the important position of the complementary sciences in the curriculum of pesantren in Java since the nineteenth century. There are many books of nahw that are very popular among santris such as al-Âjurûmiyyah, 'Imrițî, Mutammimah, and Alfiyyah Ibn Mâlik (van den Berg 1886; van Bruinessen 1990).

Aceng Zakaria was born and grew up in this learning tradition of instrumental science. Therefore, al-Muyassar also shows traces of the instrumental science roots of traditional pesantren that he had studied long before. However, he also made various modifications for the learning technique to be more systematic and practical. Therefore, the nahw then became much easier for PERSIS students to learn. The simple, systematic, and practical explanation are the specialty of Aceng Zakaria's works. Here is a comparison between al-Muyassar and al-Âjurûmiyyah:

\begin{tabular}{|c|c|}
\hline $\begin{array}{l}\text { Al-Âjurûmiyyah } \\
\text { by al-Sanhaji } \\
(1998,6)\end{array}$ & 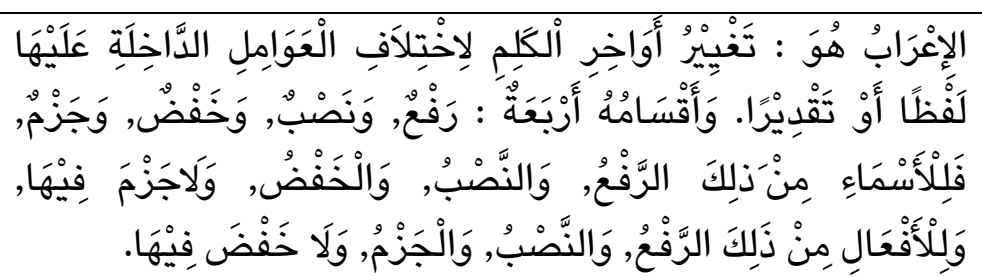 \\
\hline Translation & $\begin{array}{l}\text { I'râb is a change in the end of the Arabic sentence due to } \\
\text { the difference in internal 'âmil (position) written or } \\
\text { implied words. There are four divisions of i'râb: rafa', } \\
\text { nașab, khafad, and jazm. So, the rules of rafa', nașab, and } \\
\text { khafad apply to ism (noun), not jazm. Meanwhile, the rule } \\
\text { of rafa', nașab, and jazm apply for fi'il (verb), not khafad. }\end{array}$ \\
\hline $\begin{array}{l}\text { Al-Muyassar by } \\
\text { Aceng Zakaria } \\
(2007,11)\end{array}$ & 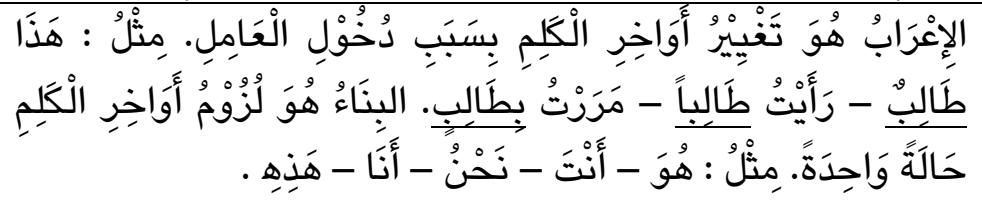 \\
\hline
\end{tabular}




\begin{tabular}{|c|c|}
\hline & 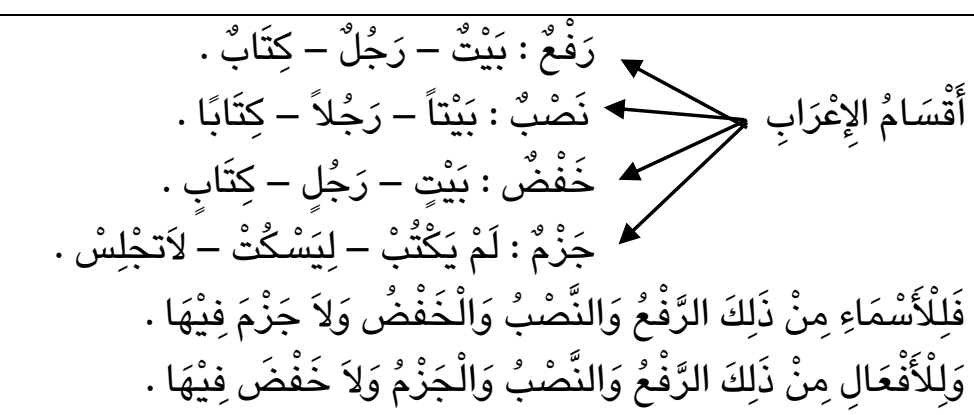 \\
\hline Translation & $\begin{array}{l}\text { I'râb is a change in the end of the Arabic sentence caused } \\
\text { by the inclusion of 'âmil. Example: hâdhâ bayt (this is a } \\
\text { house); ra'aytu tâliban (I saw a student); marartu bi tâlib (I } \\
\text { passed a student). Al-binâa' is the fixed end of the sentence } \\
\text { in one state. Example: huwa (he); anta (you); nahn (we); } \\
\text { ana (me); hâdhih (this). The division of i'râb: rafa' (for } \\
\text { example: bayt (house), rajul (male), kitâb (book); nașab (for } \\
\text { example: baytan, rajulan, kitâban); khafad (for example: } \\
\text { baytin, rajulin, kitâbin); jazm (for example: lam yaktub (he } \\
\text { doesn't write), li yaskut (to keep him quiet), la tajlis (do not } \\
\text { sit down). The rules of rafa', nașab, and khafad are applied } \\
\text { to ism (noun), not jazm. Meanwhile, the rule of rafa', } \\
\text { nașab, and jazm is applied for fi'il (verb), not khafad. }\end{array}$ \\
\hline
\end{tabular}

This comparison shows that Aceng Zakaria's al-Muyassar still cannot be separated from the sources of pesantren literature such as al-Âjurûmiyyah. This book is generally used in traditional pesantren, although recently it has also been used in modern pesantren and madrasa. This can be seen from the way of defining i'râb which shows similarities. Aceng Zakaria provides a systematic explanation of the $i^{\prime} r a ̂ b$ by providing several example of sentences and making a chart by adding some arrows. The use of al-Âjurumiyyah as a source of al-Muyassar shows that Aceng Zakaria connects his books to the kitab kunings as the references which he learned while studying in traditional pesantren. Based on his experience in the intellectual tradition of the traditional pesantren, he modified the explanation of Arabic grammar so it is easier. 
2. Al-Hidâyah and figh books in the traditional pesantren

In addition to al-Muyassar, the influence of the intellectual tradition of traditional pesantren is also seen in Aceng Zakaria's al-Hidâyah. It is visible in his discussion on the problem of adding the word sayyidina (our leader) in the ritual of salawat or invocation to the prophet which is usually read in prayer: "allahumma șalli 'alâ sayyidinâ Muhammad ...". He lists two opinions on the legal ground of adding word sayyidinâ: the traditionalist ulama and the reformist like himself. The first opinion supports the addition of the sayyidina from the well-known figh book in traditional pesantren circles, I'ânah al-Tâlibîn (vol. 1, th. 173) by 'Uthmân ibn Shatâ al-Bakrî Abû Bakr and Nihâyah al-Muhtâj (vol. 1, 2003, 530) by Shams al-Dîn al-Ramlî. Aceng Zakaria $(1407 \mathrm{H}, 39-40)$ then lists a second opinion that was against the first one and at the same time favored it. He includes his argument by directly quoting the hadith narrated by Imam Muslim, ta'liqât (commentary) of Bulügh al-Marâm and his rational argument.

$$
\text { زالمذهب الأول: }
$$

I. الأولى ذكر السيادة لأن الأفضل سلوك الأدب ـ إعانة الطالبين 179 : 179.

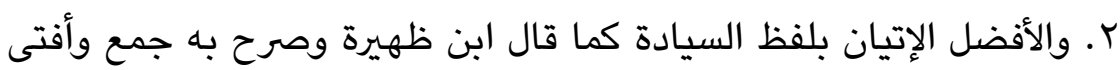

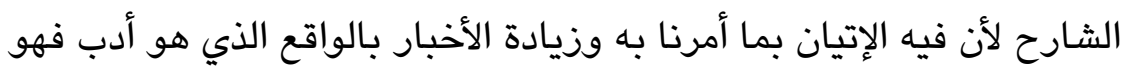

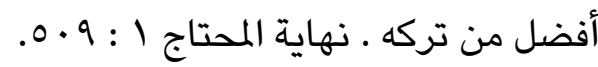

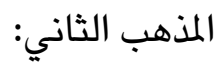
ا. وعن ابن مسعود رضي الله عنه قال: قال بشير بن سعد يا رسول الله أمرنا الله أن نصلي عليك فكيف نصلى عليك؟ فسكت ثم قال: قولوا اللهم صل على على الى اله

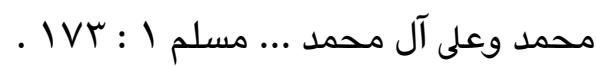
r. الأمور التعبدية من ألفاظ وغيرها لا يصح الزيادة على مالى ما ورد فيها

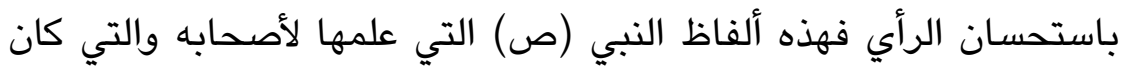

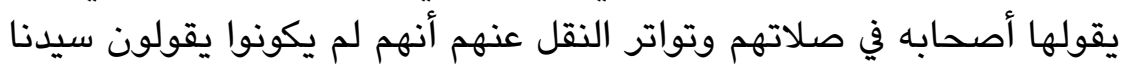

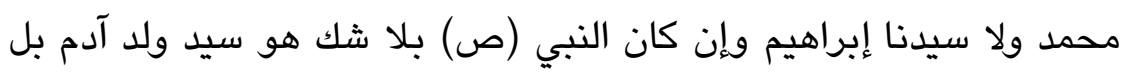

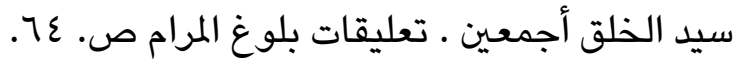




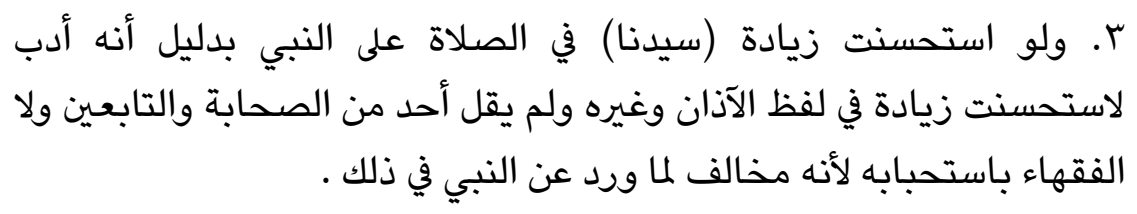

"Additional word of "sayyidinâ" in ritual of salawat or invocation to the prophet."

"First opinion of figh school: 1) Mentioning the word sayyidina because the most important point is politeness (adab). (I'ânah al-Tâlibîn vol. 1: 169). 2). Coming up with the word sayyidinâ as Ibn Zahîrah said and explained, "It has been agreed by the commentator, because it leads to what the prophet ordered and the addition of the hadith with the fact that it is adab. Saying sayyidinâ word is more important than omitting it" (Nihâyah al-Muhtâj, vol. 1: 509)."

"Second opinion of figh school: 1) A hadith of Ibn Mas'ud states: Bashîr ibn Sa'ad asked: "O Messenger of Allah, Allah has ordered us to praise you. How should we praise you?" The prophet was silent, then he said: "Say Allâhumma șalli 'alâ Muhammad wa 'alâ âli Muhammad ... (Muslim, vol. 1: 173). 2). The case of ta'abbudî (rules of worship that have been determined by the prophet) is in the form of certain words. It is not valid that there are additions (words) to what has been determined (by the Prophet), although it is for good purposes. These are the words of the prophet that he taught to his companions and then they recited it in salawat. The mutawatir narrations of hadith state that they did not read sayyidina Muhammad and neither did sayyidinâ Ibrâhîm. Meanwhile the prophet, without any doubt, is the sayyid (chief) of the son of Adam, even the ruler of all creatures (ta'liqât of Buluggh al-Marâm, 64). 3) If the addition of the word (sayyidinâ) is considered good in greeting the prophet for politeness ( $a d a b$ ) reasons, then it would definitely be good to add it to adhân and others. Meanwhile, none of the companions, the successors and figh ulamas use this word because the additional word of sayyidina deviates the narrates that came from the prophet."

The explanation of al-Hidâyah shows that Aceng Zakaria mastered the traditionalist fiqh books that he studied in traditional pesantren, namely I'ânah al-Tâlibin and Nihâyah al-Muhtâj. This made it easier for him to give different argument from the opinion of these two traditionalist kitâbs on the word sayyidinâ in salawat. He uses reformist Muslim's arguments that he quotes directly referring to hadith and rational arguments. His argument 
may tend to be polemical (khilâfiyyah), so that it can trigger a backlash when it is read by traditionalist Muslim.

\section{Aceng Zakaria and the Hybridization of Intellectual Traditions}

Aceng Zakaria, as already explained, initially grew up in the intellectual tradition of traditional pesantren in Wanaraja Garut. He then studied at Pesantren PERSIS Pajagalan in Bandung and finally joined PERSIS. He was connected to pesantren network in Java through his grandfather, Mama Zakaria or Kiai Ba'ali. The roots of traditional Islam in Aceng Zakaria's thought are very important, because it then influenced his career as PERSIS ulama until now. The roots of his traditional Islam is visible in his books such as al-Muyassar and al-Hidâyah.

The traces of the intellectual tradition of traditional Islam also can be seen in Aceng Zakaria's teaching and learning methods. The bandongan or bandungan teaching system that positions the kiai (religious teacher) as a learning subject, for instance, is also carried out by Aceng Zakaria when studying some kitâbs in the classroom. The students solemnly listened to the description of the kitâb, ending with a question and answer session about the problem being discussed by traditionalist Muslims. His breadth of views on religious issues, both from the perspective of traditionalist and reformist, is the typical of Aceng Zakaria's thought. This is understandable considering his traditional intellectual background which made him know the map of traditional Islamic scholarship very well. Therefore, it was easy for him to explain and at the same time refute it. His basic Islamic knowledge that he mastered are nahww, șaraf, balâghah, theology, Islamic mysticism, fiqh, uṣ̂ul alfigh, mantiq (logic), and sirah (the biography of Muhammad). He got these Islamic knowledge when studying in Wanaraja with Ajengan "Engku" (Ahmad Kurkhi), his own father, Muallim Anshor and Kiai Payumi. Therefore, Aceng Zakaria's teaching still reflects the general trend of learning traditions in various pesantren in Java (Dhofier 1980, 21).

These Islamic knowledge is obtained by Aceng Zakaria from standard kitab kunings that are used as the curriculum of traditional pesantren in Java (Kuswandi et al. 2021). It can be seen in al-Âjurûmiyyah used as a main reference for al-Muyassar; as well as I'ânah al-Tâlibîn and Nihâyah al-Muhtâj which are used as references for al-Hidâyah. In addition, Wanaraja as the place where Aceng Zakaria lived is one of the areas of Sundanese pesantren. C. Snouck Hurgronje, for instance, noted that there was a figure of Kiai 
Mulabaruk who lived in the area that is close to Citangtu, Cipari and Cilame, where Aceng Zakaria was born and studied. Mulabaruk had studied in Tegalsari Surabaya. He studied at the pesantren of Kiai Hasan Besari. He was the key to the spread of his former students throughout Priangan (Laffan 2011, 152).

However, Aceng Zakaria did not only study at traditional pesantren. His close relation with E. Abdurrahman, a second ulama of PERSIS after A. Hassan, while studying at the Pesantren PERSIS Pajagalan Bandung improved his knowledge. There was a meeting point between teacherstudent who were both formed in the intellectual tradition of traditional Islam. E. Abdurrahman knows who have deep knowledge of the basic traditional Islamic knowledge like himself. Therefore, the figure of Aceng Zakaria immediately impressed him shortly and became one of $\mathrm{E}$. Abdurrahman's main students. There was a hybridization of traditional Islam into a reformist Islamic culture that grew within Aceng Zakaria's thought. The depth of knowledge about traditional Islamic scholarship is mixed and matched into the context of reformist Islamic thought as initiated by both A. Hassan and E. Abdurrahman.

In addition to teaching and learning, the traces of traditional Islam in Aceng Zakaria's thought can also be seen in his hundreds works. No matter how strong his identity as a reformist and puritanist, the traces of Islamic traditionalist roots are never lost from him. Several best-selling works of Aceng Zakaria in the field of instrumental science, Quranic commentary, hadith, prayers, and ethics books show traces of traditional Islam. In addition to al-Muyassar and al-Hidâyah, the traces of his traditional Islam present in his other books such as Zâd al-Muta'allim (the Supplies of Learning) that reminds us of the classic kitâb taught in pesantren, namely alZarnûjî's Ta'lìm al-Muta'allim; the book of Do'a-Do'a Sehari-hari (Daily Prayers) reminds us of the book of al-Adhkâr by Abû Zakariyâ al-Nawawî; and many others.

The peculiarities of Aceng Zakaria's works lies in its efforts to make a systematic explanation. The discussion of Arabic grammar which is gradual, long, and complicated in instrumental science kitabs become more concise, easier, and practical. This shows the distinctive character of reformist activists who try to break away from traditional Islamic traditions which use commentary (sharh), super-commentary (hâshiyah), marginal notes (hâmish), 
summary (mukhtasar), poem (manzumah), and others. They then turn to systematized works like modern-style books.

The commentary or sharh tradition became prominent in the traditional pesantren along with the centrality of the kiai figure who became the center of intellectual authority in front of his students. Through sharh tradition, students maintain the Islamic scholarship chain (sanad) accompanied by humility ( $t a^{\prime} z \hat{\imath} \mathrm{m}$ ) in front of their kiais by simply commenting on the main text of the kiai's work or previous ulamas (Wijoyo 1997, 323-7). This is different from the tradition of the reformist Muslim which left the sharh tradition and moved to the print publication of modern-style books. The reformists emphasize the independence of thought and religious authority of the students in front of previous works of kiais and ulama. Therefore, peculiarities of modernist ulamas's works are the text explanation that are systematic so that easily understood by students and all readers.

Therefore, Aceng Zakaria's works published by reformist publishers shows traces of reformist ideas that use critically analysis of the socioreligious situation in Indonesia. The main figures of PERSIS such as A. Hassan, M. Natsir, and Isa Anshary, for instance, previously published books and magazines that emphasize critical analysis of religious issues in the early twentieth century. Their critics receive good responses from Muslim society in Indonesia. Aceng Zakaria tries to follow the same path by publishing many books containing his responses to religious issues discussed within the Muslim community such as al-Hidâyah fi Masâ'il alFiqhiyyah al-Muta'âridah; Menguak Hakikat Syahadat (Revealing the truth of the Islamic creed), Bai'at dan Jamaah Muslimin (Bai'at and the movement of Jama'ah Muslimin); Haramkah Isbal dan Wajibkah Jenggot? (Is isbâl forbidden and beard obligatory?); Studi Pemikiran Aliran-aliran Sesat dan Menyesatkan (The study of heretical schools of thought); Mengapa Harus Memilih Pemimpin Muslim? (Why should we choose the Muslim leaders?); Sikap Seorang Muslim dalam menghadapi Virus Corona (The Muslim attitudes in dealing with the corona virus), and others (Fauzan et al. 2021, 218-22).

The findings of this study at the same time are to break the assumption of some scholars who tended to deny the connection between Pesantren PERSIS and the intellectual tradition network of traditional pesantren. Pesantren PERSIS is considered not to be connected with other pesantren networks in West Java, because the reformist Muslim organization 
considered it different from the intellectual tradition of traditional pesantren (Kusdiana 2013, 240). However, the intellectual tradition of Pesantren PERSIS, on the one hand, still maintains the intellectual tradition of the traditional pesantren, although there are some modifications. The Quranic commentary of al-Jalâlayn, for instance, is still used in the Quranic commentay learning at the Pesantren PERSIS in Rancabango Garut, as seen in the study of Nurtawab (2018). The instrumental science kitâbs such as alÂjurûmiyyah and Alfiyah Ibn Mâlik were also studied. However, several "new" books were later introduced as learning material resources for Pesantren PERSIS students such as several works of Aceng Zakaria: Al-Muyassar fi ' $\mathrm{Ilm}$ al-Nahw (1985), al-Kâfi fì 'Ilm al-Sarf (1993), al-Bayân fì 'Ulûm al-Qur'ân (1996), Mustalâh al-Hadith (1996), and others. Aceng Zakaria's works are still based on material sources of traditional pesantren such as al-Âjurûmiyyah, Alfiyah Ibn Mâlik, 'Imritî, Tanqîh al-Qawl, and others which are mixed and matched with books written by modern ulamas.

Therefore, the figure of Aceng Zakaria reflects a PERSIS activist who struggles from the bottom to integrate the intellectual tradition of traditional pesantren into reformist Islamic traditions. He reflects the typical PERSIS ulama who was inherited his predecessors, especially A. Hassan and E. Abdurrahman. This study contributes to the importance of considering that the modernist-traditionalist categorization is not a clear-cut typology as seen in the study of Noer (1963). There are gradations and dynamics between these two typologies. Therefore, it is not appropriate for scholars to use the typology rigidly. It is true that these two typologies grow and develop side by side at the public discourse, but in the individual realm, the main figures at that time are very likely to have a fluid of thought that cannot be clearly divided into that two categories.

In addition, one of the main figures who characterizes the development of PERSIS in the third generation is reflected in the figure of Aceng Zakaria. Howard M. Federspiel thoroughly did research the first generation of PERSIS between 1923-1958 such as A. Hassan, M. Natsir and Isa Anshary (Federspiel 2001). Dadan Wildan, Tiar Anwar Bachtiar and Pepen Irpan Fauzan then continue with their studies on the development of the second generation of PERSIS such as M. Natsir, Isa Anshary, E. Abdurrahman and one of the third generations, A. Latief Muchtar (Wildan 1995; 2000; Bachtiar and Fauzan 2019). 
In the midst of the lack of studies on the first and second generations of PERSIS, apart from the popular figures such as A. Hassan, M. Natsir, Munawar Chalil, and E. Abdurrahman, it is important to study the traces of the third generation of PERSIS, especially after 1980 until now such as Fackrudin al-Kahiry, A. Latief Muchtar, Shiddiq Amien, Usman Sholehuddin, Ikin Sadikin, Abdurrahman Ks., Entang Mukhtar ZA., Emon Sastranegara, and others. The PERSIS young generation today may be unfamiliar with the names of many figures of PERSIS such as A. Qadir Hassan, Komaruddin Shaleh, I. Sudibja, E. Abdullah, A. Ghazali, Muh. Syarief Sukandi, M. Rusyad Nurdin, Aisyah Wargadinata, Aminah Dahlan, and many others.

The challenges of the intellectual tradition of PERSIS under the leadership of Aceng Zakaria are the dynamic situation faced by their predecessors at the beginning of the twentieth century. It is necessary to reintroduce the insights of intellectual tradition of traditional Islam for PERSIS students in order to understand the roots of Islamic scholarship in the Malay-Indonesia archipelago which stretches from the seventeenth century to the present. This study is important to strengthen the intellectual culture within PERSIS activists in the midst of the weak personality of the national figures, the limited number of PERSIS members, educational institutions and business charities, and the lack of response to national issues. Therefore, it is the obligation of PERSIS members to continue the intensity of the studies to produce the intellectual works that connected with socio-religious discourse on the national and global stage.

\section{Conclusion}

The discussion shows that the basis of intellectual tradition in the modernist Muslim works cannot be separated from the traces of intellectual tradition of traditional Islam in Indonesia. This can be seen in the intellectual experience of Aceng Zakaria and his works, especially alMuyassar and al-Hidâyah. Aceng Zakaria as a PERSIS ulama was originally educated in the intellectual tradition of traditional pesantren in the midtwentieth century. He succeeded in making his experience of studying at traditional pesantren to be an important sources in his intellectual career. Both al-Muyassar and al-Hidâyah emphasize the connectivity of Aceng Zakaria's thought with the intellectual tradition of pesantren as seen in the large scope of his works on Islamic studies as well as his main focus and literature sources. However, Aceng Zakaria as a modernist also made 
modifications with systematic and practical explanation in his works. It is a figure of reformist ulama who reflects the continuity of the intellectual tradition in the PERSIS circle since the era of A. Hassan in the early twentieth century until today.

\section{References}

Amalia, A. 2017. "Analisis Gradasi Materi Sharaf dalam Buku Belajar Tasrif Sistem 20 Jam karya KH. Aceng Zakaria.” al-Mahâra 3(1): 102-23.

Arifianto, Alexander R. 2017. "Islam Nusantara \& Its Critics: The Rise of NU's Young Ulamas.” RSIS Commentary No. 018-23 January. https://www.eurasiareview.com/24012017-islam-nusantara-and-itscritics-the-rise-of-nus-young-clerics-analysis/.

Asnan, Gusti. 2015. "Tradisi Rantau dan Diaspora: Kasus Mingkabau, Melayu dan Bugis." In Sejarah Kebudayaan Islam Indonesia: Tradisi, Intelektual, dan Sosial, vol. 2, eds. Taufik Abdullah and Endjat Djaenuderadjat. Jakarta: Direktorat Jenderal Kebudayaan Kementerian Pendidikan dan Kebudayaan.

Bachtiar, Tiar Anwar, and Fauzan, Pepen Irpan. 2019. Sejarah Pemikiran dan Gerakan Politik Persis. Bandung: Persis Pers.

Burhani, Ahmad Najib. 2004. "The Muhammadiyah's Attitude to Javanese Culture in 1912-1930: Appreciation and Tension." MA. Thesis. Leiden University.

Burhani, Ahmad Najib. 2018. Islam Nusantara as a Promising Response to Religious Intolerance and Radicalism. Trends in Southeast Asia. No.21. ISEAS-Yusof Ishak Institute.

Burhanudin, Jajat. 2005. "Aspiring for Islamic Reform: Southeast Asian Requests for Fatwas in al-Manar." Islamic Law and Society 12(1): 9-26.

Bush, Robin. 2009. Nahdlatul Ulama and the Struggle for Power within Islam and Politics in Indonesia. Singapore: ISEAS.

Dhofier, Zamakhsyari. 1980. "The Pesantren Tradition: A Study of the Role of the Kyai in the Maintenance of the Traditional Ideology of Islam in Java." Dissertation. Australian National University. 
Fauzan et al., Pepen Irpan. 2021. KH. Aceng Zakaria, Ulama Persatuan Islam. Garut: LPPM STAI PERSIS Garut.

Federspiel, Howard M. 2001. "Islam and Ideology in the Emerging Indonesian State: The Persatuan Islam (PERSIS), 1923-1957. Leiden-Boston-Koln: Brill.

Federspiel, Howard M. 2002. "Modernist Islam in Southeast Asia: A New Examination." The Muslim World 92.

Hakim, Gausulfardi. 2009. "K.H.R. Abdullah bin Nuh dan KaryaKaryanya." BA. Thesis. Universitas Indonesia.

Hamdani, Hamdani. 2021. "Defending Islam Nusantara at the Frontline, Experiment to shape moderatism among Non-structural Nahdliyyin Community." Islam Nusantara 2(1): 21-39.

DOI: https://doi.org/10.47776/islamnusantara.v2i1.103.

Hasyim, Syafiq. 2018. Islam Nusantara dalam Konteks: Dari Multikulturalisme hingga Radikalisme. Yogyakarta: Gading.

Horikoshi, Hiroko. 1975. "The Dar ul-Islam Movement in West Java (194862): An Experience in the Historical Process." Indonesia 20: 58-86.

Horikoshi, Hiroko. 1976. "A Traditional Leader in a Time of Change: The Kijaji and Ulama in West Java." Dissertation. University of Illinois at Urbana-Champaign.

Iskandar, Mohammad. 2001. Para Pengemban Amanah, Pergulatan Pemikiran Kiai dan Ulama di Jawa Barat, 1900-1950. Yogyakarta: Matabangsa.

Kusdiana, Ading. 2013. "Jaringan Pesantren di Priangan 1800-1945." Dissertation. Bandung: Universitas Padjadjaran.

Kuswandi, Iwan, Tobroni Tobroni, Akhsanul In'am, Khozin Khozin, and Asmoni Asmoni. 2021. "Interconnection Model of Morals-ReasoningResearch in Pesantren Curriculum." Ulul Albab: Jurnal Studi Islam 22(1): 69-91.

DOI: https://doi.org/10.18860/ua.v22i1.11611.

Laffan, Michael. 2011. The Makings of Indonesian Islam, Orientalism and the Narration of a Sufi Past. Princeton: Princeton University Press. 
MacRaild, Donald M., and Taylor, Avram. 2004. Social Theory and Social History. New York: Palgrave MacMillan.

Millie, Julian. 2009. Splashed by the Saint, Ritual reading and Islamic sanctity in West Java. Leiden: KITLV Press.

Minhaji, Akh. 1997. "Ahmad Hassan and Islamic Legal Reform in Indonesia (1887-1958). Dissertation. Institute of Islamic Studies McGill University.

Mustafa, Ii Baihaqi. 2005. KH. M. Rusyad Nurdin: Ulama, Pejuang, Politikus, Pemimpin Demokrat, Pendidik, dan Pendakwah. Bandung: MULTIPRO incollaboration with LPESKI YUAVIN.

Nakamura, Mitsuo. 1976. "The Crescent Arises over the Banyan Tree: A Study of the Muhammadijah Movement in a Central Javanese Town.” Dissertation. Cornell University.

Nakamura, Mitsuo. 1981. "The Radical Traditionalism of the Nahdlatul Ulama in Indonesia: A Personal Account of the $26^{\text {th }}$ National Congress, June 1979, Semarang." Southeast Asian Studies 19(2): 187204.

Noer, Deliar. 1963. "The Rise and Development of the Modernist Muslim Movement in Indonesia during the Dutch Colonial Period (19001942)." Dissertation. Cornell University.

Nugraha, Roni, and Rohmana, Jajang A. 2021. "Reformist Muslim Discourse in the Sundanese Commentary of the Qur'ân: E. Abdurrahman's Commentary on Surah al-Hujurat, Jurnal Studi IlmuIlmu Al-Qur'an dan Hadis. Vol. 22, No. 2 (Juli 2021), 345-71.

DOI: https://doi.org/10.14421/qh.2021.2202-04.

Nurtawab, Ervan. 2018. "Jalalayn Pedagogical Practice: Style of Qur'an and Tafsir Learning in Contemporary Indonesia,” Ph.D. Thesis. Monash University.

al-Ramlî, Shams al-Dîn Muḥammad ibn Abî al-Abbâs Aḥmad ibn Hamzah ibn Shihâb al-Dîn. 2003. Nihâyah al-Muhtâj ilâ Sharh al-Minhâj fî al-Fiqh 'alâ Madhâhib al-Imâm al-Shâfi î Radivallâh 'anh, vol. 1. Beirut: Dâr alKutub al'-'Ilmiyyah. 
Rohmana, Jajang A. 2017. "Polemik Keagamaan dalam Tafsir Malja' atTalibin Karya K.H. Ahmad Sanusi.” Suhuf: Jurnal Pengkajian Al-Qur'an dan Budaya 10(1): 25-57.

DOI: https://doi.org/10.22548/shf.v10i1.207.

Rosidi, Ajip. ed. 2000. Ensiklopedi Sunda, Alam, Budaya, dan Manusia. Jakarta: Pustaka Jaya.

Sa'adah, Rizka Rahmaniah. 2018. "Tafsir Surat Al-Fatihah Karya Aceng Zakaria (Analisis Metodologi dan Corak Tafsir).” BA. Thesis. Universitas Islam Negeri Sunan Ampel Surabaya.

Saefuddin, Encang. 2014. Fiqhud Dakwah: KH. Drs. Shiddiq Amien, MBA. Bandung: Mujahid Press.

Sahal, Akhmad, and Aziz, Munawir eds. 2015. Islam Nusantara dari Ushul Fiqh hingga Paham Kebangsaan. Bandung: Mizan Pustaka.

al-Ṣanhâjî, Abû 'Abd Allâh Muhạmmad ibn Muḥammad ibn Dâwud. 1998. Matn al-Âjurûmiyyah. Riyad: Dâr al-Sumay' î.

Selamat, Kasmuri. 2020. "Salafi-Progressive: Islamic Education Thinking Discourses of K.H. Aceng Zakaria.” Dinamika Ilmu 20(1): 107-22.

DOI: https://doi.org/10.21093/di.v20i1.2162.

Shața al-Dimyâtîn, Sayyid Abî Bakr al-Mashhûr bi al-Sayyid al-Bakrî ibn alSayyid Muḥammad. n.d. I'ânah al-Ṭâlibîn, vol. 1. Cairo: Dâr Iḥ̂â' alKutub al-'Arabiyyah.

Shihab, Alwi. 1995. "The Muhammadiyah Movement and Its Controversy with Christian Mission in Indonesia." Dissertation. The Temple University.

Stearns, Peter N. ed. 1994. Encyclopedia of Social History. New York \& London: Garland Publishing Inc.

Tamney, Joseph. 1980. "Modernization and Religious Purification: Islam in Indonesia." Review of Religious Research 22(2): 207-18.

DOI: https://doi.org/10.2307/3510661.

van Bruinessen, Martin. 1990. "Kitab Kuning: Books in Arabic Script Used in the Pesantren Milieu." Bijdragen tot de Taal, Land-en Volkenkunde 146: 226-69. 
van Bruinessen, Martin. 2003. "Review of Howard M. Federspiel, "Islam and Ideology in the Emerging Indonesian State: The Persatuan Islam (PERSIS), 1923-1957, Leiden: Brill, 2001.” Int. J. Middle East Stud. 35.

van Bruinessen, Martin. 2018. Indonesian Muslim in a Globalising World: Westernization, Arabisation, and Indigenising Responses. RSIS Working Paper No. 311, Singapore: S. Rajaratnam School of International Studies.

van den Berg, L.W.C. 1886. "Het mohammedaansche godsdienstonderwijs op Java and Madoera en de daarbij gebruikte arabische boeken." TBG 31: $518-55$.

Wijoyo, Alex Soesilo. 1997. "Shaykh Nawawî of Banten: Texts, Authority, and the Gloss Tradition." Ph.D Thesis. Columbia University.

Wildan, Dadan. 1995. Sejarah Perjuangan Persis 1923-1983. Bandung: Gema Syahida.

Wildan, Dadan. 1997. Yang Da’i Yang Politikus: Hayat dan Perjuangan Lima Tokoh Persis. Bandung: Rosda Karya.

Wildan, Dadan. 2000. Pasang Surut Gerakan Pembaharuan Islam di Indonesia: Potret Perjalanan Sejarah Persatuan Islam. Bandung: Persis Press.

Zakaria ibn Ahmad Kurhi, Aceng. 2007. al-Muyassar fì 'Ilm al-Nahw, vol. 1. Garut: Ibn Azka Press.

Zakaria ibn Ahmad Kurhi, Aceng. 1407 H. al-Hidâyah fì Masẩil Fiqh Muta'âridah. Pesantren Persatuan Islam Garut.

Interview with KH. Aceng Zakaria, chairman of PERSIS, at Sekolah Tinggi Agama Islam PERSIS (STAIPI) Garut on Thursday, April 1, 2021 at 9 am.

Interview with Pepen Irpan Fauzan, a lecturer at Sekolah Tinggi Agama Islam PERSIS (STAIPI) Garut on Sunday, October 10, 2021 at 8 am. 